\title{
Herbaceous Biomass Dynamics and Net Primary Produc- tion Following Chemical Control of Honey Mesquite
}

\author{
R.K. HEITSCHMIDT, R.D. SCHULTZ, AND C.J. SCIFRES
}

\begin{abstract}
The effect of honey mesquite (Prosopis glandulosa var. glandulosa Torr.) control on herbaceous growth dynamics, forage production, and root and crown biomass was investigated in 1979 and 1980 on a site aerially treated with a 1:1 mixture of 2,4,5-T plus picloram at $0.6 \mathrm{~kg} / \mathrm{ha}$ in May 1974. Density, height, and canopy of honey mesquite trees 5 years after treatment were 248 plants/ha, $0.9 \mathrm{~m}$, and $3.1 \%$, respectively, compared to 963 plants $/ \mathrm{ha}, 2.2 \mathrm{~m}$, and $34.6 \%$, respectively, in the adjacent untreated control plot. Yet, there were no differences between sprayed and untreated plots after 6 and 7 growing seasons relative to species composition, growth dynamics, and production of herbaceous plants. Averaged across years and treatments, estimated aboveground net primary production was $2,525 \mathrm{~kg} / \mathrm{ha}$. Crown and root biomass in the top 10 $\mathrm{cm}$ of the soil profile averaged 685 and $3,837 \mathrm{~kg} / \mathrm{ha}$, respectively, with no significant treatment or year effects. Lack of treatment difference partially validates a conceptual model presently used for economic analysis of herbicide sprays for honey mesquite control. Further, it supports the hypothesis that honey mesquite trees provide critical habitat for the more productive midgrasses indigenous to this site; and that elimination of this habitat in sparse stands of the shrub subsequently limits post-treatment herbage response.
\end{abstract}

Dense stands of honey mesquite often suppress herbage production with the degree of suppression primarily a function of stand density and the innate productivity potential of the treated site (Scifres and Polk 1974, Dahl et al. 1978, McDaniels et al. 1978,

Authors are associate professor and former graduate research assistant, Texas Agricultural Experiment Station, Vernon; and Thomas M. O'Connor professor, Department of Range Science, Texas A\&M University, College Station.

Appreciation is extended to the E. Paul and Helen Buck, Waggoner Foundation Inc. for financial support and the W.T. Waggoner Estate Ranch for study area and treatment installation.

Report is published with approval of the Director, Texas Agricultural Experiment Station, as TA 20218.

Manuscript accepted 9 May 1985.
Brock et al. 1978, Jacoby et al. 1982, Bedunah and Sosebee 1984). Degree of suppression is difficult to quantify because of spatial and temporal variation in herbage response following mesquite control. Major factors affecting herbage response are initial stand density, method of control, effectiveness of control, condition and composition of understory vegetation at the time of treatment, and post-treatment climatic and livestock grazing conditions (Scifres 1980).

Research in the Rolling Plains of Texas has indicated that the increase in herbaceous standing crop during the first 3 to 4 growing seasons following control of honey mesquite is generally accompanied by a shift in overall species composition toward more productive species (McDaniel et al. 1978, McDaniel et al. 1982). However, longer-term herbage responses in this region relative to seasonal growth dynamics, species composition, and aboveground net primary productivity (ANPP) have not been addressed. The objective of this study was to quantify these effects 6 and 7 growing seasons after treatment. Our central hypothesis was that control of honey mesquite would continue to enhance herbage production 6 and 7 years post-treatment.

\section{Materials and Methods}

\section{Study Area}

The study area was located $37 \mathrm{~km}$ southwest of Vernon, Texas, on the W.T. Waggoner Estate Ranch ( $33^{\circ} 50$ N., $99^{\circ} 25^{\prime}$ W.; elevation $384 \mathrm{~m}$ ). Climate is continental and semiarid. Mean annual precipitation at Vernon is $65.2 \mathrm{~cm}$. Peak rainfall months are May $(11.9 \mathrm{~cm})$ and October $(7.7 \mathrm{~cm})$. The average frost-free growing season is 224 days extending from late March to November (Koos et al. 1962). Mean annual air temperature is $17^{\circ} \mathrm{C}$. Average daytime maximum and minimum temperatures range from $36^{\circ} \mathrm{C}$ in July to $-2.5^{\circ} \mathrm{C}$ in January (U.S. Dep. Comm. 1980).

The study was conducted during the 1979 and 1980 growing 
seasons. Precipitation at Vernon was slightly above the longterm average during the 1979 growing season $(70.5 \mathrm{~cm})$ and well below average during the 1980 growing season $(41.1 \mathrm{~cm})$. Ambient air temperatures were near the longterm average during the 1979 growing season. Temperatures during the 1980 growing season were above average with daytime maximums from June through September 1980 consistently exceeding $37.8^{\circ} \mathrm{C}$ with the maximum during the 42-day period from 23 June to 3 August never less than $37.8^{\circ} \mathrm{C}$.

\section{Experimental Area}

Twice-replicated 0.25 -ha subplots were located in two, 6.4-ha brush management treatment plots originally established in May 1974. Treatments were an untreated control and an aerial application of a 1:1 mixture of 2,4,5-T [2,4,5-(trichlorophenoxy)acetic acid] and picloram (4-amino-3,5,6-trichloropicolinic acid) in a diesel oil-water (1:3) emulsion at $0.6 \mathrm{~kg} / \mathrm{ha}$. The 4 four plots were located on Tillman clay loam soils. The Tillman series is a member of the fine, mixed, thermic family of Typic Paleustolls. It is a deep, well-drained, upland soil located on $0-1 \%$ slopes. Range site classification is clay loam. The plots were grazed as a unit by cattle at a light rate of stocking during each dormant season.

The native vegetation of the 6.4-ha treatment plots was characterized in early June 1974 prior to herbicide application (Haas 1978). Averaged across plots, honey mesquite canopy was $26 \%$. Density of honey mesquite trees averaged 556 plants/ha. The understory vegetation was a mixture of short- and midgrass type communities. Based on June 1974 standing crop estimates, the dominant shortgrasses were buffalograss [Buchloe dactyloides (Nutt.) Englem.], a warm-season perennial, and little barley (Hordeum pusillum Nutt.), a cool-season annual. The dominant coolseason midgrass was Texas wintergrass (Stipa leucotricha Trin. and Rupr.). The dominant warm-season midgrasses were sand dropseed [Sporobolus cryptandrus (Torr.) Gray], white tridenns [Tridens albescens (Vasey) Woot. and Standl.], and red threeawn (Aristida longiseta Steud.). Total herbage standing crop in the untreated area averaged $1,147 \mathrm{~kg} /$ ha with $1,116 \mathrm{~kg}$ of grass and 31 $\mathrm{kg}$ of forbs. Total herbage standing crop in the treated area averaged $1,164 \mathrm{~kg} /$ ha with $1,138 \mathrm{~kg}$ of grass and $26 \mathrm{~kg}$ of forbs.

The pre-treatment herbaceous standing crop data gathered in 1974 was also stratified by community typc. Communitics dclineated were midgrass upland, dense shortgrass, sparse shortgrass, and midgrass draw (Haas 1975). Based on percent composition by dry weight, the midgrass upland communities were dominated by buffalograss $(27 \%)$ and Texas wintergrass (16\%). The shortgrass dense communities were dominated by buffalograss $(74 \%)$ while the shortgrass sparse communities were dominated by buffalograss $(51 \%)$ and sand dropseed $(14 \%)$. The midgrass draw communities were dominated by buffalograss (11\%), western wheatgrass ( Agropyron smithii Rydb.) (16\%), sideoats grama [Bouteloua curtipendula (Michx.) Torr.] (31\%), and various species of forbs (15\%).

The honey mesquite canopy in the 6.4-ha untreated plots was $32.8 \%$ by 1976 (Haas 1973). Estimated canopy cover in the treated plots in 1976 was $2.2 \%$. Estimated woody plant cover in 1979 in the untreated and treated subplots was $34.6 \%$ and $3.1 \%$, respectively (Schultz 1982). Woody plant density in the untreated subplots in 1979 was 963 plants / ha as compared to 248 plants / ha in the treated subplots. Average tree height in the untreated plots was $2.2 \mathrm{~m}$. Average tree height in the treated plots was $0.9 \mathrm{~m}$. The dominant herbaceous species growing on the study area during the 1979 and 1980 growing seasons were buffalograss, Texas wintergrass, little barley, and Japanese brome (Bromus japonicus Thumb.), a coolseason annual grass. Other common warm-season perennial grasses were tumble windmillgrass (Chloris verticillata Nutt.), tumblegrass [Schedonnardus paniculatus (Nutt.) Trel.], red threeawn, and sand dropseed. Common sixweeks grass [Vulpia octoflora Rydb.] and rescuegrass [Bromus unioloides (Willd.) H.B.K.], 2 annual shortgrasses, were common during spring. Common perennial forbs were heath aster (Aster ericoides L.), western ragweed
(Ambrosia psilostachya D.C.), silverleaf nightshade (Solanum elaeagnifolium Cav.), and American germander (Teducrium canadense L.). The most frequent annual forbs were common broomweed (Xanthocephalum dracunculoides D.C.) and woolly plantain (Plantago purshii R. \& S. var. purshii).

\section{Methods}

On-site precipitation was measured with a standard rain gauge. Soil water content was determined gravimetrically from interspaces separating the shrubs in all subplots on a weekly basis. Samples were collected at $10-\mathrm{cm}$ increments to a depth of $100 \mathrm{~cm}$ when possible. Extremely dry conditions during summer 1980 limited the sample depth to the top $10 \mathrm{~cm}$ of the soil profile.

Aboveground standing crop was sampled by the frequent harvest method utilizing ten, 0.25 -m circular quadrats in each subplot on each sample date. Location of quadrats was entirely random. When individual honey mesquite trees physically restricted the placement of a quadrat, a second location was randomly selected. Vegetation was clipped at ground surface and dried at $60^{\circ} \mathrm{C}$ to a constant weight. All biomass was separated by species into 3 categories: live, recent dead (current year's dead), and old dead (previous year's dead). Harvest dates were approximately once a month from March through October in 1979 and from May through September in 1980.

Belowground biomass was sampled in June of both years to estimate vertical root distribution in $10-\mathrm{cm}$ increments. An $80-\mathrm{cm}$ core, $5.1 \mathrm{~cm}$ in diameter, was taken from the center of each quadrat after the aboveground herbaceous material was harvested. Four additional $7.5-\mathrm{cm}$ diameter cores were collected in each harvest quadrat to estimate total root biomass in the top $10 \mathrm{~cm}$ of the soil profile. Cores were washed following the procedures outlined by Lauenroth and Whitman (1971). Samples were dried at $60^{\circ} \mathrm{C}$ to a constant weight, separated into either crown or root tissue, weighed, and ashed at $610^{\circ} \mathrm{C}$ to determine organic matter.

Aboveground net primary production (ANPP) was estimated by summing peak current year's (live + dead) standing crop by species and species group (Singh et al. 1975). Species groups consisted of all species contributing $<5 \%$ to the total ANPP in either treatment in either year. Data were analyzed utilizing various analysis of variance models (Steel and Torrie 1960). Tukey's Q-values were utilized for mean separations when F-values were significant ( $\alpha=$ 0.05 ). Arcsin transformations for percentage composition data were utilized when appropriate.

\section{Results}

\section{Soil Water Content}

Because soil water content did not differ among treatments, regardless of sampling date or depth, data were pooled across treatments to illustrate trends during the 2 growing seasons (Fig. 1). Soil water contents were closely coupled to amount and temporal distribution of rainfall, and were considerably less throughout the 1980 growing season when compared to 1979 . Schultz (1982) found no differences between treatments in soil water potentials measured at $10-\mathrm{cm}$ increments. He reported average soil water potentials of $0.03,0.10,0.50$, and $1.5(-\mathrm{MPa})$ occurred when soil water content in the top $10 \mathrm{~cm}$ of the soil profile averaged 20.8 , $15.5,12.0$, and $11.2 \%$, respectively.

\section{Herbage Growth Dynamics}

Vegetative growth was initiated in early spring in 1979 (Fig. 2). Peak live standing crop occurred in June in both treatments. Estimated peaks were 1,750 and $1,600 \mathrm{~kg} / \mathrm{ha}$ in the untreated and sprayed plots, respectively. Live material was present throughout the 1979 growing season with approximately $700 \mathrm{~kg} /$ ha harvested from each treatment in October. Recent dead biomass began to accumulate in late $A$ pril as the cool-season grasses and forbs began to senesce. Quantity of recent dead standing crop progressively increased thereafter as the warm-season plants matured. Quantity 


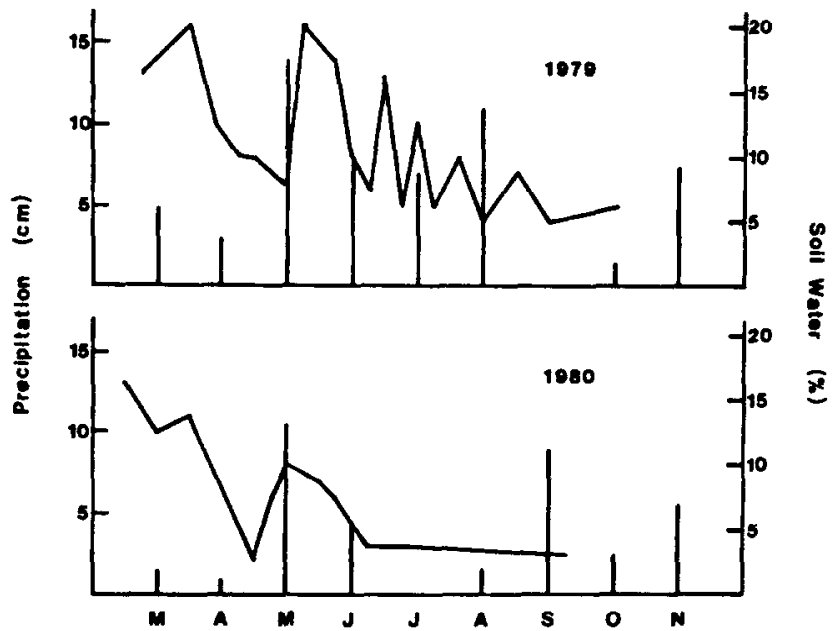

Fig. 1. Monthly precipitation (cm) at Vernon (vertical lines) and soil water (\%) in top $10 \mathrm{~cm}$ at study sites during 1979 and 1980 growing season.

of old dead standing crop decined rapidly during spring with only minimal amounts present by summer.

Herbage dynamics in 1980 were substantially different than in
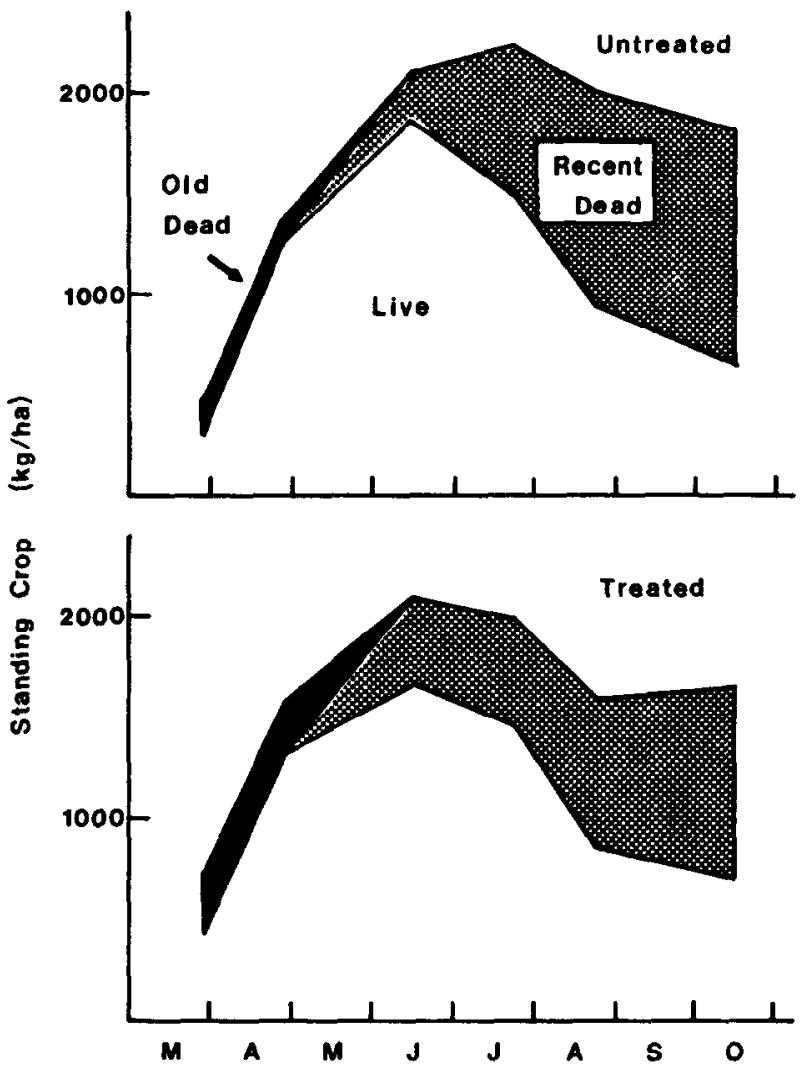

Fig. 2. Aboveground biomass dynamics on untreated and treated plots during 1979 growing season.

1979 because the drought which began in late May (Fig. 1) effectively eliminated all vegetative growth after early June (Fig. 3). Peak live biomass in both treatments was approximately $40 \%$ less in 1980 than 1979 with no live material present in either treatment by late July. As the live plants senesced during the summer, dead material increased dramatically; however, quantity of recent dead standing crop declined during the late summer of 1980 as opposed to the steady increase observed in 1979. Decline in recent dead
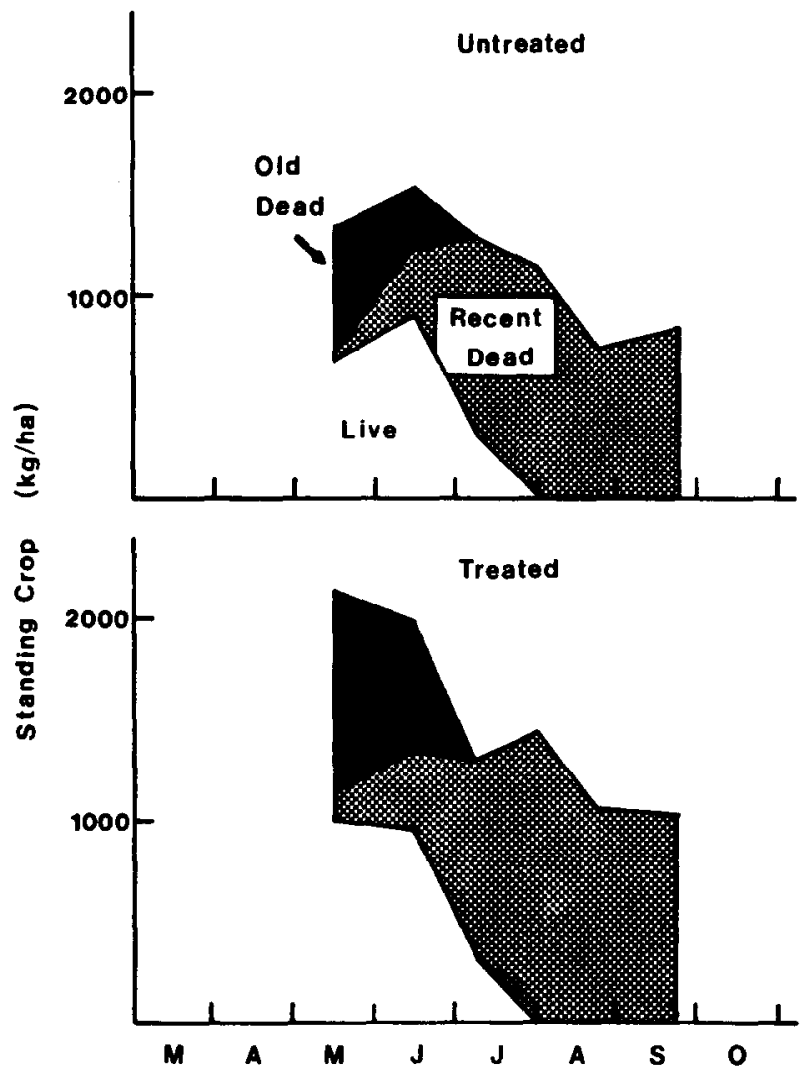

Fig. 3. Aboveground biomass dynamics on untreated and treated plots during 1980 growing season.

standing crop indicates transfer of material into the litter component. Such a transfer in 1980 would be expected since the recent dead material in 1980 was probably considerably older than on comparable calendar dates in 1979. Dynamics of the old dead standing crop in 1980 were similar to 1979.

Statistical analyses of the live, recent dead, and old dead biomass estimates across dates generally indicated significant $(\alpha=0.01)$ species, date and species-by-date interaction effects regardless of tissue category. Treatment and treatment interaction effects, however, were not significant $(\alpha=0.10)$. We attributed the lack of significant treatment effects to a lack of differences between treatments in species composition. Buffalograss was the dominant species in both treatments and accounted for 70 to $80 \%$ of the total standing crop on any given harvest date on the untreated plots, and from 45 to $56 \%$ of the total standing crop harvested on any given sample date in the treated plots.

\section{Aboveground Net Primary Production (ANPP)}

ANPP varied significantly $(\alpha=0.01)$ between years and among species (Fig. 4). The year effect was caused by the 1980 drought, which reduced total ANPP 27\% relative to 1979 estimates. The species effect resulted from differences among species in ANPP. A significant $(\alpha=0.01)$ year-by-species interaction effect reflected the influence of differences in growing conditions between years on the growth of the different species.

\section{Belowground Biomass}

Estimated root biomass in the top $10 \mathrm{~cm}$ of the soil profile was $3,837 \mathrm{~kg} / \mathrm{ha}$ with differences between treatments and years not significant $(\alpha=0.05)$. Likewise, crown biomass $(685 \mathrm{~kg} / \mathrm{ha})$ and vertical root distribution were unaffected by treatment or year. Approximately $38 \%$ of the roots to a depth of $80 \mathrm{~cm}$ occurred in the 


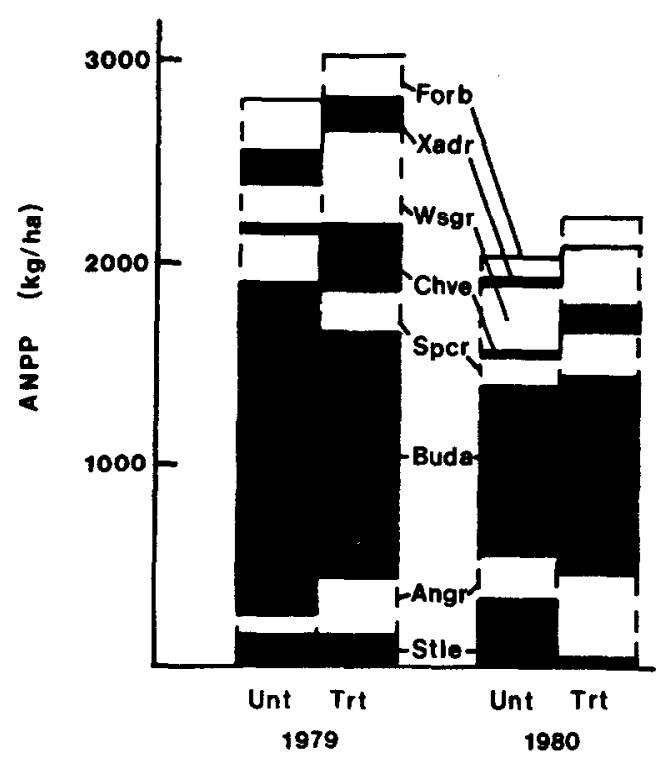

Fig. 4. Estimated above ground net primary production $(\mathrm{kg} / \mathrm{ha})$ for individual species and/or species groups on untreated (Unt) and treated (Trt) plots during 1979 and 1980 . Species and species groups are Texas wintergrass (Stle), annual grasses (Angr), buffalograss (Buda), sand dropseed (Spcr), tumble windmillgrass (Chve), other warm-season grasses (Wsgr), common broomweed (Xadr), and other forbs (Forb).

top $10 \mathrm{~cm}$ of the soil profile, and about $55 \%$ occurred in the top 20 $\mathrm{cm}$. Both the quality and pattern of distribution of roots were similar to those reported for other North American grasslands (Sims and Singh 1978).

\section{Discussion and Conclusion}

The results of this study indicate no difference in total herbage production between sprayed and unsprayed honey mesquite plots 6 and 7 growing seasons after treatment primarily because species composition was quite similar in both treatments. We believe the results provide strong ccological evidence in support of the conceptual models of post-treatment herbage response proposed by Whitson and Scifres (1982) for economic analyses of honey mesquite control. Our belief is based upon the rather broad generalization that the herbage response following control of honey mesquite in these grasslands is most often related to the response of those grasses growing beneath the canopy of the trees at the time of treatment (Brock et al. 1978, McDaniel et al. 1978, Jacoby et al. 1982, McDaniel et al. 1982). It follows that since these are generally the most productive grasses that grow on a site, the magnitude and duration of post-treatment herbage response is closely related to their response. It is therefore not surprising that control of sparse stands of honey mesquite and/or control of honey mesquite on sites with low productivity potential and/or in excellent range condition generally limit the magnitude of the herbage response following control, while post-treatment rainfall patterns and grazing intensity generally affect both the magnitude and duration of the response (Scifres and Polk 1974, Scifres et al. 1974, Dahl et al. 1978, McDaniel et al. 1978). Basically, our data suggest that the post-treatment response of midgrasses growing beneath the canopy at the time of treatment was of insufficient magnitude and/or duration to induce a statistically significant treatment effect 6 and 7 years after spraying.

An ecological explanation of these data must center on the basic concepts of habitat and succession. We hypothesize that the presence of honey mesquite trees on this site may be critical for the survival and propagation of substantial populations of midgrasses. The hypothesis is based on an assumption that the ameliorated micro-environment within the canopy area of the honey mesquite trees (Brock 1978) is the critical factor controlling the relative abundance of most midgrasses on this site. We found no evidence that would support the hypothesis that the honey mesquite trees growing on our study site were actually limiting the abundance of midgrasses in the interstitial areas. Rather, we believe that buffalograss would be the dominant grass species on this site in the presence or absence of honey mesquite trees regardless of livestock grazing regime. Results of Foster et al. (1984) further support this belief. They reported that buffalograss was the dominant grass on a Tillman clay loam site located about $5 \mathrm{~km}$ from our study site. Their site supported only a sparse stand of honey mesquite trees, and it had not been grazed by domestic livestock at other than a light rate during the dormant season for a minimum of 10 years.

The relative differences between years and treatments in the productivity of various species provide biological evidence in support of our hypothesis. For example, Texas wintergrass (Stle) production increased from 160 to $335 \mathrm{~kg} /$ ha in the untreated plots from 1979 to 1980 but decreased from 155 to $60 \mathrm{~kg} / \mathrm{ha}$ in the treated plots (Fig. 4). We believe these differences, although not statistically significant, reflect the interaction effect of the 1980 drought and the presence or absence of mesquite trees. The preferred habitat of Texas wintergrass in this region is beneath the canopy of honey mesquite (Brock et a. 1978). Previous research has shown that the canopy area of both honey and velvet mesquite $[P$. glandulosa var. velutina (Woot.) Sarg.] tends to ameliorate the xeric environment characteristic of most rangelands (Tiedemann and Klemmedson 1973, Brock 1978). We assume in this instance that the honey mesquite canopies effectively reduced the severity of the 1980 drought within the canopy area which, in turn, enhanced Texas wintergrass production. Similar results have been reported in south Texas by Scifres et al. (1982). They found that grass production decreased following control of a sparse stand of huisache (Acacia farmesiana Willd.) in years of below-average rainfall. They attributed this decline primarily to an overall reduction in Texas wintergrass production which resulted because of the elimination of huisache canopy, the preferred habitat of Texas wintergrass.

The same interaction effect was also evidenced by the response of the other warm-season grasses (Wsgr) (Fig. 4), which were those midgrasses that grew primarily within honey mesquite canopy areas. The magnitude of their response, however, was less dramatic than that for Texas wintergrass.

In summary, we believe our interpretation of the results of this study provide a conceptual model that may enhance our ability to predict more accurately the magnitude and duration of herbage response following spraying of honey mesquite in north Texas. Hopefully, future studies will be undertaken at other locations to specifically test the validity of our hypothesis as an ecological explanation of post-treatment forage responses following mesquite control.

\section{Literature Cited}

Bedunah, D.J., and R.R. Sosebee. 1984. Forage response of a mesquitebuffalograss community following range rehabilitation. J. Range Manage. 37:483-487.

Brock, J.H. 1978. Influence of honey mesquite and its control on zonal vegetation patterns. Ph.D. Thesis, Texas A\&M Univ., College Station.

Brock, J.H., R.H. Haas, and J.C. Shaver. 1973. Zonation of herbaceous vegetation associated with honey mesquite in northcental Texas. $p$ 187-189. In: D.N. Hyder (ed), Proc. First Int. Rangeland Congr. Soc. Range Manage. Denver, Colo.

Dahl, B.E., R.E. Sosebee, J.P. Goen, and C.S. Brumley. 1978. Will mesquite control with 2,4,5-T enhance grass production? J. Range Manage. 31:129-131

Foster, M.A., C.J.Scifres, and P.W. Jacoby. 1984. Herbaceous vegetationlotebush [Ziziphus obtusifolia (T. \& G.) Gray var. obtusifolia] interactions in north Texas. J. Range Manage. 37:317-320. 
Haas, R.H. 1975. Monitoring rangeland improvement following brush control. Annu. Rep. E. Paul and Helen Buck Waggoner Foundation, Inc. Dep. Range Sci., Texas A\&M Univ., College Station.

Haas, R.H. 1978. Monitoring rangeland improvement following brush control. Annu. Rep. E. Paul and Helen Buck Waggoner Foundation, Inc. Dep. Range Sci., Texas A\&M Univ., College Station.

Jacoby, P.W., C.H. Meadors, M.A. Foster, and F.S. Hartmann. 1982. Honey mesquite control and forage response in Crane County, Texas. I. Range Manage. 35:424-426.

Koos, W.M., J.C. Williams, and M.L. Dixon. 1962. Soil survey of Wilbarger County, Texas. USDA-SCS., Texas Agr. Exp. Sta.

Lauenroth, W.K., and W.C. Whitman. 1971. A rapid method for washing roots. J. Range Manage. 24:308-309.

McDaniel, K.C., R.H. Haas, and J.H. Brock. 1978. Range condition trends following control of honey mesquite (Prosopis glandulosa var. glandulosa) on deep hardlands in northcentral Texas. p. 530-533. In: D.N. Hyder (ed), Proc. First Int. Rangeland Cong., Soc. Range Manage. Denver, Colo.

McDaniel, K.C., J.H. Brock, and R.H. Hass. 1982. Changes in vegetation and grazing capacity following honey mesquite control. J. Range Manage. 35:551-557.

Schultz, R.D. 1982. Net primary production and seasonal herbaceous dynamics following brush management. Ph.D. Thesis, Dep. Range Science, Texas A\&M Univ., College Station.
Scifres, C.J. 1980. Brush management. Principles and practices for Texas and the southwest. Texas A\&M Univ. Press, College Station.

Scifres, C.J., M.M. Kothmann, and G.W. Mathis. 1974. Range site and grazing system influence regrowth of honey mesquite. J. Range Manage. 27:97-100.

Scifres, C.J., and D.B. Polk, Jr. 1974. Vegetation response following spraying a light infestation of honey mesquite. J. Range Manage. 27:462465.

Scifres, C.J., J.L. Mutz, R.E. Whitson, and D.L. Drawe. 1982. Interrelationship of huisache canopy cover with range forage on the Coastal Prairie. J. Range Manage. 35:558-562.

Sims, P.L., and J.S. Singh. 1978. The structure and function of ten western North American grasslands. II. Intra-seasonal dynamics in primary producer compartments. J. Ecol. 66:547-572.

Singh, J.S., W.K. Lauenroth, and R.K. Steinhorst. 1975. Review and assessment of various techniques for estimating net aerial primary production in grasslands for harvest data. Bot. Rev. 41:181-232.

Steel, G.D., and J.H. Torrie. 1960. Principles and procedures of statistics. McGraw-Hill Book Co., New York.

Tiedemann, A.R., and J.O. Klemmedson. 1973. Effect of mesquite on physical and chemical properties of the soil. J. Range Manage. 26:27-29.

U.S. Department of Commerce. 1980. National Oceanic and Atmospheric Administration. 1980. Climatological data, Texas. Vol. 85. No. 13.

Whitson, R.E., and C.J. Scifres. 1981. Economic comparisons of alternatives for improving honey mesquite infested rangeland. Texas Agr. Exp. Sta. Bull. 1307. 